\title{
Energy Efficiency of Cooling Load through The Glass Facade of Office Buildings in Surabaya
}

\author{
Ulil Albab ${ }^{1}$ and Tri Joko Wahyu Adi ${ }^{1}$
}

\begin{abstract}
The aims of this article is to obtain an alternative type of glass on the envelope buildings of full glass on all surface envelope, cost of glazed facades and to obtain energy efficiency of cooling load through the glass facade of office buildings in Surabaya. The shape of the building in this article uses a simulation of regular form (squares) and differences in building orientation. The calculation method is uses the OTTV method (Overall Thermal Transfer Value) for the value of heat gain through the building envelope and the CLTD method (Cooling Load Temperature Difference) to calculate the cooling load affected by the glass facade. The results obtained in this article simulation show that the most efficient value is double glazing with using $S C \leq 1.9$ and $U$ value glass $\leq 2.6 \mathrm{~W} / \mathrm{m} 2 \mathrm{~K}$, so that the energy efficiency of the cooling load obtained can decrease until $6 \%$. The savings were obtained at the value of OTTV is $25.60 \mathrm{~W} / \mathrm{m} 2$ with the price of glass facade in the amount of Rp. 4,005,333/m².
\end{abstract}

Keywords-Energy Efficiency, Cooling Load, Façades, Office Building.

\section{INTRODUCTION}

The use of glass on the facades of office buildings provides comfort and psychological effects for its residents. Glass as a direct link between the outer and inner environments of buildings is a key factor in determining energy performance in buildings, especially in cooling energy requirements. The use of the glass field as part of the facade (building envelope) is an environmental control element, which modifies the external environment into the environment inside the building for the comfort of occupants [1]. Therefore, many designs of office buildings (high-rise buildings) use glass as a building facade for comfort and work productivity for its occupants. Glass material and its hadow elements have a major influence on the creation of a climate in the building.

High-rise buildings with glass curtain walls are potential energy uses where most energy is needed to activate the air system to ensure a certain level of comfort in it. The amount of energy needed for air conditioning systems is largely determined by heat gain (cooling load) that occurs through glass curtain walls with conduction, convection and thermal radiation. The wider the wall of the glass curtain, the greater the energy use of the building [2].

\footnotetext{
${ }^{1}$ Ulil Albab and Tri Joko Wahyu Adi are with Departement of Management Technology, Institut Teknologi Sepuluh Nopember, Surabaya, Indonesia. E-mail: ulilalbab1202@gmail.com; trijokowahyuadi@gmail.com.
}

The main reason for architects and building owners to design buildings with curtain walls is commercial appeal. The wide glass window displays the view around the building which can increase the value of the building [3].

External heat from the windows and walls of a typical office building in Jakarta is around 63\%, while internal heat from equipment, lighting and occupancy is around $37 \%$. This shows enormous energy saving opportunities through carefully designed and appropriate building envelopes to reduce air cooling loads. Most of the energy in buildings in Indonesia is used by HVAC systems regardless of the type of building. In terms of office buildings in Jakarta, HVAC contributes $55 \%$ of the building's total energy consumption [3].

The importance of studying glass as one of the buildings' envelop components during the design phase, as well as its effects on the energy consumption of the building. that building orientation and glass specifications can control heat losses and gains, which subsequently reflected on the heating and cooling demands, which lead to saving energy and money [4].

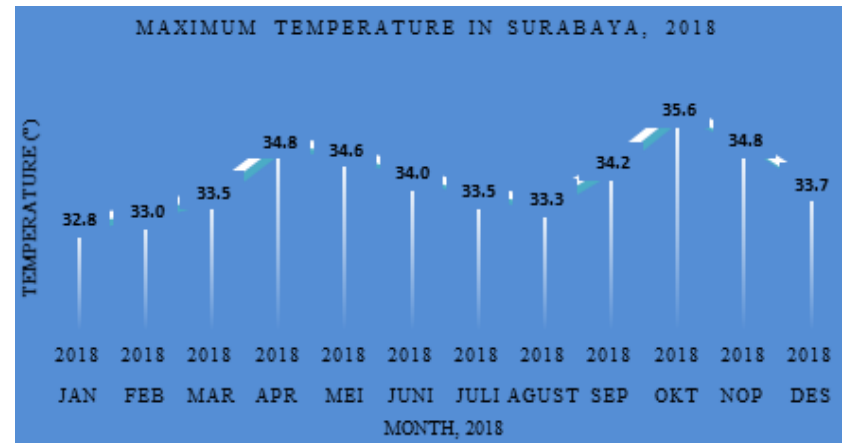

Figure 1. Average temperature in Surabaya 2018.

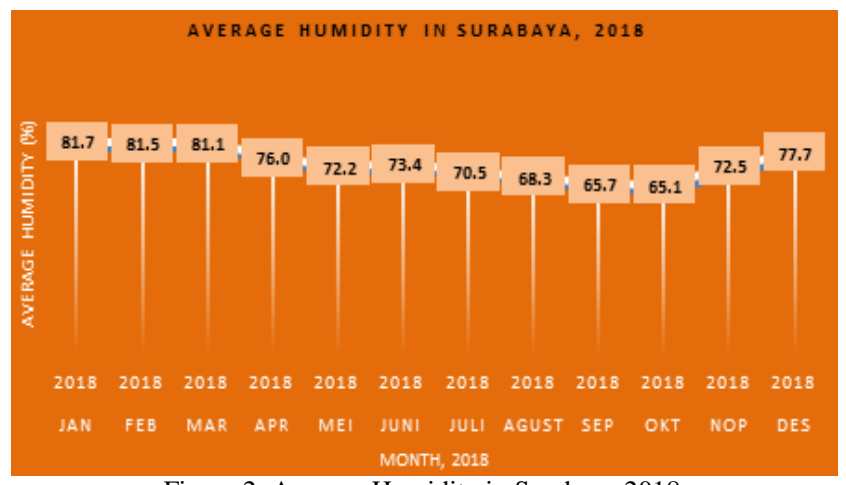

Figure 2. Average Humidity in Surabaya 2018. 
The main problem in creating energy-efficient buildings comes from the activation of solar heat in buildings and through the air conditioning system. Limiting OTTV is one of the energy efficiency strategies [5].

The simulation office building is located in the city of Surabaya. Geographically, the city of Surabaya is between 07,210 South Latitude to 112,540 East Longitude. Surabaya is a lowland with an altitude of 3-6 meters above sea level, except in the South, 25-50 meters above sea level [6].

Surabaya is one of the tropical cities in Indonesia, the temperature level is quite high, based on BMKG data in 2018 the average temperature is $34^{\circ} \mathrm{C}$ can be seen in Figure 1. This causes high year-round sun exposure to building facades that affect the space inside the use of cooling energy in space. Air humidity in the city of Surabaya is quite high throughout the year, based on BMKG data in 2018 with an average humidity of $75 \%$ can be seen in Figure 2.

The main aims of this article is to obtain a type of facade glass and analyze the energy efficiency of cooling loads in the most optimal glass facade of an office building. The research in this article was conducted by simulating the shape of regular form and the difference in orientation of the building. The building facade simulation was conducted in Surabaya, because Surabaya became one of the cities in Indonesia having a tropical climate with an average temperature $34^{0} \mathrm{C}$.

\section{LITERATUR REVIEW}

Building envelopes are material materials and structures that cover buildings and function the same as skin in humans. Building Facade is defined as the face of the building. The building envelope of glass material is called curtain wall and can be defined as a load-bearing outer wall which is generally assembled from repetitive industrial assembly elements (glass, aluminum, ordinary steel, stainless steel) and produced under quality control strict

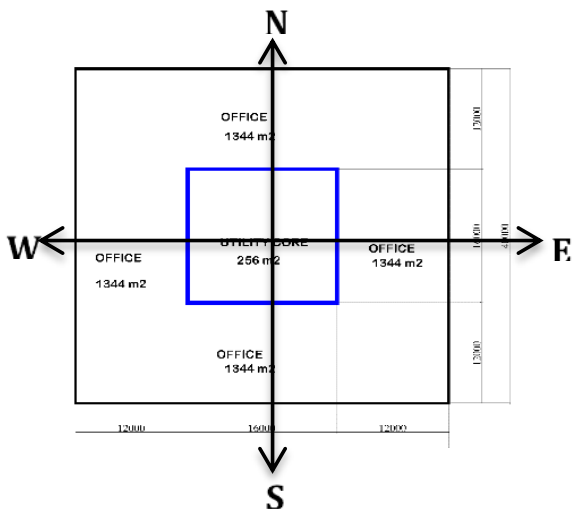

The $1^{\text {st }}$ simulation orientation on West, East, North, South ones [2]. Building envelopes are building elements that wrap around buildings, namely transparent walls and roofs (skylights) or those that are not transparent. Most thermal energy moves through these elements. The building envelope is also a part of getting direct sunlight [7].

The function Building envelopes consist of opaque components (eg walls) and phenestration systems or translucent components (such as windows) that separate the interior of buildings from the outside environment. Building envelopes provide protection against undesirable external environmental influences such as heat, radiation, wind, rain, noise, pollution etc. Building envelope has an important role in reducing energy consumption for cooling and lighting. In medium and high-rise buildings, the walls are much larger than the roof area. Therefore, the design of the vertical building envelope, especially the window, must be done carefully to avoid excessive heat entering the building [7].

OTTV is a value determined as a design criteri for the walls and glass of the outer part of a conditioned building (equipped with an air system) to replace energy use. OTTV takes into account the elements of heat gain through the external wall of a building, such as: heat conduction through opaque walls and glass windows as well as solar radiation through glass windows. SNI 6389 of 2011 assign that Value of OTTVmay not more 35 watts/m2 [7].

The foundation of an energy efficient building starts with its design process. The main issue in creating an energy efficient building comes from the absorption of the building's solar heat load through its air conditioning system. Aligning the direction of the building's façade to East and West and choosing light colors for wall finish are some examples of the common design practice to reduce solar heat input. Limiting OTTV (Overall Thermal Transfer Value) is one of the energy efficiency strategies [5].

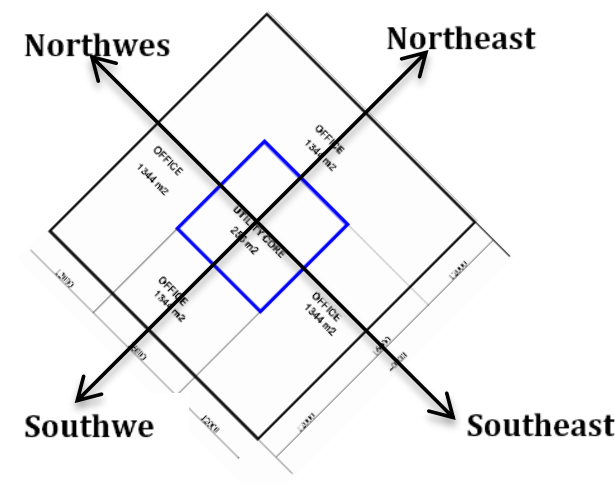

The $2^{\text {nd }}$ simulation orientation on Southwest, Northwest. Northeast. Southeast

Figure 3. The simulation on orientation differences. 
OTTV is a value determined as a design criteri for the walls and glass of the outer part of a conditioned building (equipped with an air system) to replace energy use. OTTV takes into account the elements of heat gain through the external wall of a building, such as: heat conduction through opaque walls and glass windows as well as solar radiation through glass windows. SNI 6389 of 2011 assign that Value of OTTV may not more 35 watts/m2 [7].

OTTV for each area of the outer wall of a building, must be calculated through the equation, the following basic equations shall be used:

OTTV $=\alpha\left[\mathrm{UW}^{*}(1-\mathrm{WWR}) * \mathrm{TDek}\right]+\left(\mathrm{Uf}^{*} \mathrm{WWR} * \Delta \mathrm{T}\right)+$ $(\mathrm{SC} * \mathrm{WWR} * \mathrm{SF})$

where:

$\alpha=$ Sun radiation absorption, depending on the material and color of the exterior wall

Uw $=$ Thermal transmittance of opaque wall (Watt $\left./ \mathrm{m}^{2} \cdot \mathrm{K}\right)$.

WWR = Window-to-wall ratio

TDek = Equivalent temperature difference for wall $\left(10^{\circ} \mathrm{K}\right.$ for brick wall)

SC = Shading coefficients of fenestrations, specified by the manufacturer (Asahimas)

SF $=$ Solar factor $\left(\mathrm{W} / \mathrm{m}^{2}\right)$, depends on building orientation $=130$ for North $(\mathrm{N}), 113$ for North East (NE),112 for East (E), 97 for South East (SE), 97 for South (S), 176 for South West (SW), 243 for West (W), 211 for North West (NW)

Uf $=$ Thermal transmittance of fenestration (Watt/m².oK)

$\Delta \mathrm{T}=$ Temperature difference between exterior (Surabaya area is $34^{\circ} \mathrm{C}$ ) and interior design condition $25^{\circ} \mathrm{C} .\left(9^{0} \mathrm{~K}\right)$

Then calculate the value of RTTV (Roof Thermal Transfer Value) which has almost the same meaning as OTTV, the difference is that RTTV is a value set as design criteria for roof cover, ordinary roof (not transparent) or equipped with skylight (transparent). The RTTV calculation in this article uses an ordinary roof (without skylights), the following equation used:

$\mathrm{RTTV}=\alpha \cdot\left(\mathrm{U}_{\mathrm{r}} \times \mathrm{TD}_{\mathrm{Ek}}\right)$

where :

$\alpha=$ absorbance of solar radiation;

Ur = average roof thermal transmittance $(\mathrm{W} / \mathrm{m} . \mathrm{K})$;

TDEk = Equivalent temperature difference $(\mathrm{K})$. (refers to the table).

Cooling Load is the total amount of heat energy that must be removed in units of time from the cooled room. This load is needed to deal with external and internal heat loads. External heat load is caused by heat entering through conduction (walls, ceilings, glass, partitions, floors), radiation (glass), and convection (ventilation and infiltration). Internal heat load is caused by heat arising from people/occupants, lights, and equipment/machinery [8].
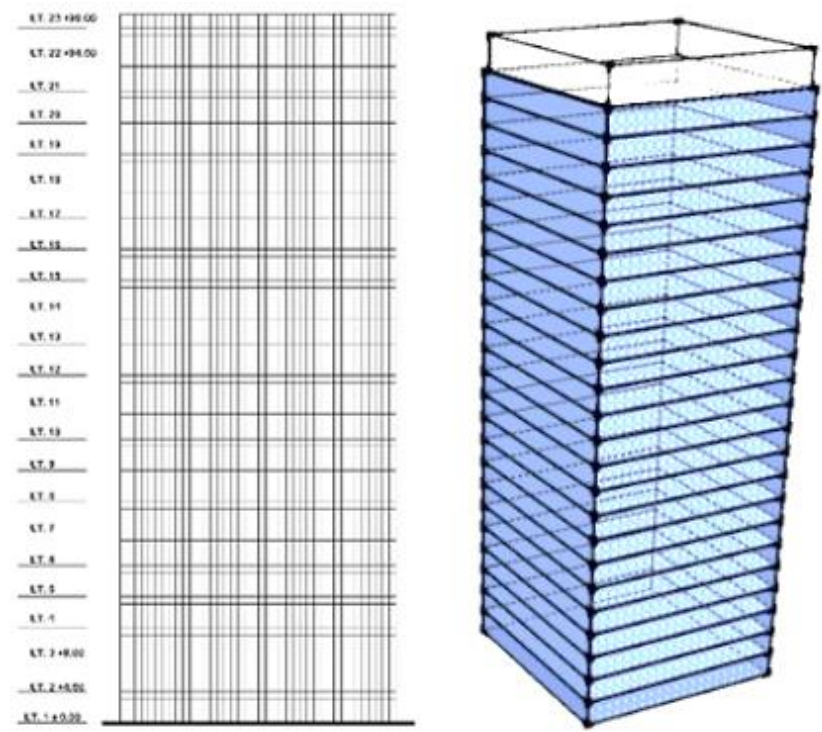

Figure 4. The shape façade simulation office building.

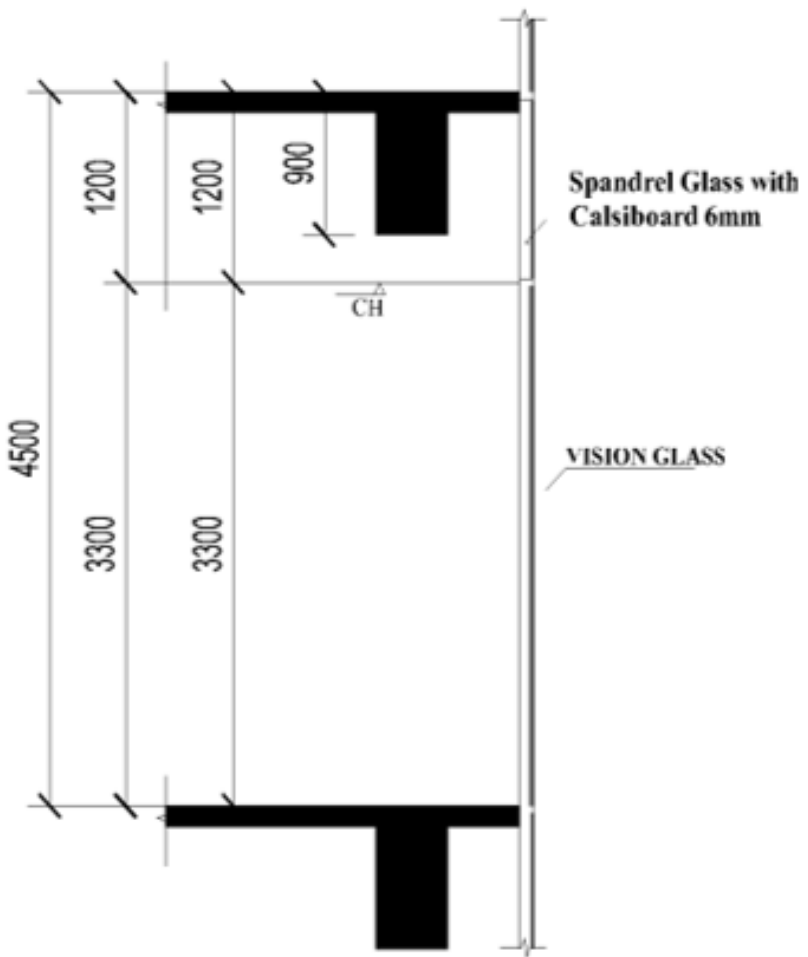

Figure 5. Section façade of office building.

Cooling load calculation is needed to resolve external and internal heat loads. External heat loads are caused by heat entering through conduction (walls, glass, partitions, floors), radiation (glass), and convection (ventilation and infiltration). Internal heat load is caused by heat arising from people/occupants, lights, and equipment/machinery. 
The $1^{\text {st }}$ International Conference on Business and Management of Technology (IConBMT)

August 3rd 2019, Institut Teknologi Sepuluh Nopember, Surabaya, Indonesia

The formula for calculating cooling load uses the CLTD method [8].

Calculation of CLTD with heat on the condition of the room can be seen with the following equation used;

1. Load of Solar Radiation Through Glass

$\mathrm{q}=\mathrm{A} \cdot(\mathrm{SC}) \cdot(\mathrm{SCL})$

where:

$\mathrm{q}=$ Cooling load from solar radiation, $\mathrm{W}$

A $\quad=$ Outer glass surface area, $\mathrm{m} 2$

$\mathrm{SC} \quad=$ Shading coefficient

SCL = Solar cooling load factor with or without shading device, $(\mathrm{W} / \mathrm{m} 2)$

2. Sun Conduction Through Glass, Roofs and Walls

$\mathrm{Q}=\mathrm{U} \cdot \mathrm{A} .(\mathrm{CLTD})$

where :

$\mathrm{Q}=$ Cooling Load, $\mathrm{W}$

$\mathrm{U}=$ The heat transfer coefficient is designed for the roof or wall or for Glass, W/(m2.K)

A $=$ The surface area of the roof, outer wall or outer glass, $\mathrm{m} 2$

CLTD $=$ Difference in temperature of cooling load for roofs, walls or glass.

\section{Occupants}

qsensibel $=\mathrm{N}$ (penambahan $\mathrm{Q}$ sensibel).(CLF)

Where :

$\mathrm{N}=$ the amount of people in the room, the addition of sensible and latent heat from the occupants.

$\mathrm{CLF}=$ Cooling load factor according to occupancy hours.

4. Lighting

$\mathrm{q}=\mathrm{W} \cdot \mathrm{F}_{\mathrm{ui}} \cdot \mathrm{F}_{\mathrm{sa}} \cdot(\mathrm{CLF})$

Where :

$\mathrm{W}=$ Electrical power from lighting in the room $(\mathrm{W} / \mathrm{m} 2)$
$\mathrm{F}_{\mathrm{ui}} \quad=$ Factor of lighting usage

$\mathrm{F}_{\mathrm{sa}} \quad=$ Tolerance factor

CLF = Cooling load factor according to occupancy hours

5. Plug Load

$q=$ P.Ef.(CLF)

Where:

$\mathrm{P}=$ Electric plug power used $(\mathrm{W} / \mathrm{m} 2)$

$\mathrm{E}_{\mathrm{f}} \quad=$ Efficiency factor

CLF = Cooling load factor according to occupancy hours.

\section{Methodology}

\section{A. Simulation}

The simulation in this article uses a building shape from a box with the same length and width of the building (ragular form) with a full glass surface. Simulations conducted with different orientations can be seen at Figure 3 these two differences will be used in the simulation of this article. The office building simulation parameters that will be used for analysis are as follows:

Shape of building : : Regular form (square) Building orientation:W,E,N,S $\quad\left(1^{\text {st }}\right.$ simulation), SW, NW, NE, SE ( $2^{\text {nd }}$ simulation $)$

Building dimensions $\quad: 40 \mathrm{~m}$ (length), $40 \mathrm{~m}$ (width)

Height floor to floor $\quad: 4.5$ meters

Total building floor $: 22$ floors

Typical floor area $\quad: 1,600 \mathrm{~m}^{2}$

Net lettable floor area $\quad: 1,344 \mathrm{~m}^{2}$

Roof area $\quad: 1,600 \mathrm{~m}^{2}$

Gross floor area $\quad: 35,200 \mathrm{~m}^{2}$

Nett lettable area $\quad: 29,568 \mathrm{~m}^{2}(1,344 \mathrm{~m} 2 /$ floor $)$

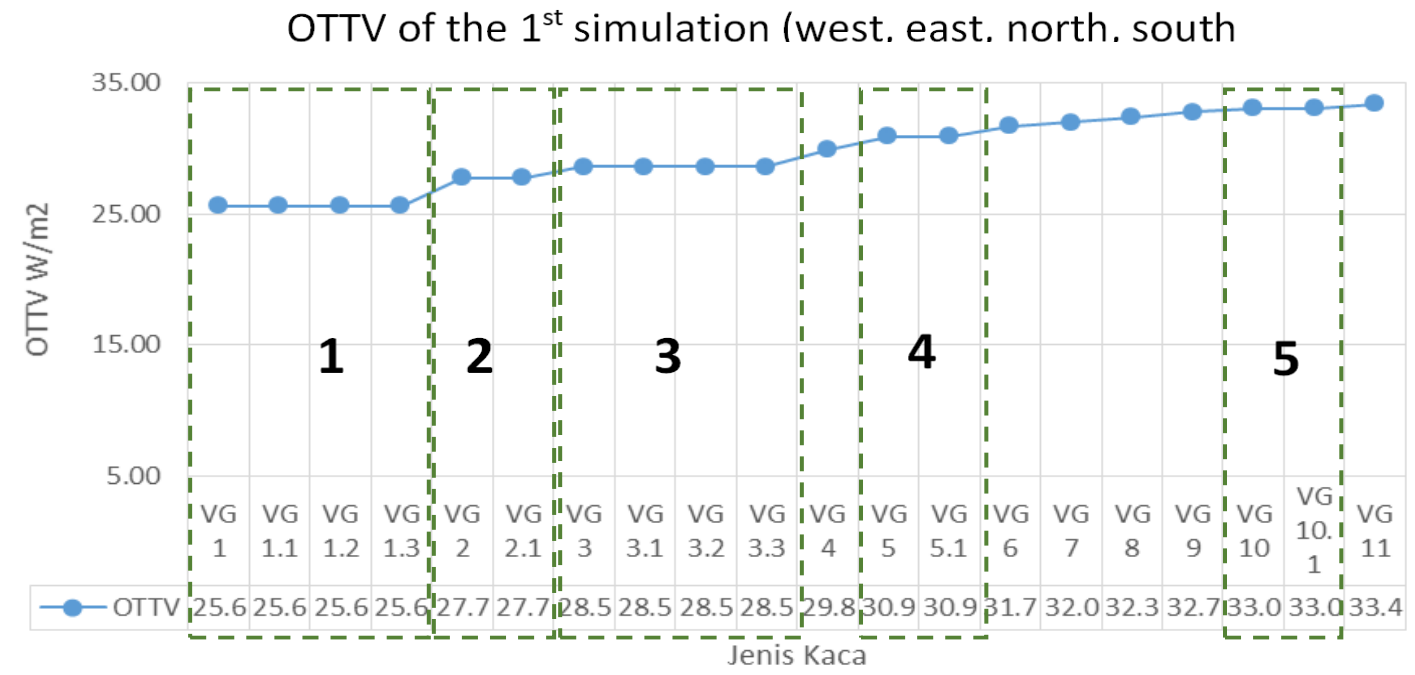

Figure 6. The Result OTTV with Glass types of the $1^{\text {st }}$ simulation 
The characteristics of simulation materials on the facade of office buildings can be seen in Figure 4 the facade material used uses glass on all surfaces, alumunium profiles and spandrels with calsiboard $6 \mathrm{~mm}$ can be seen in Figure 5. The spandrel material uses a glass $8 \mathrm{~mm}$ thickness with the type of Planible $G$ glass, while the calsiboard frame uses a hollow with size 20x40.

\section{B. Methodology OTTV (Overall Thermal Transfer Value) and CLTD (Cooling Load Temperature Difference)}

The OTTV concept includes three basic elements of heat transfer through the envelope building, namely: heat conduction through opaque walls, solar radiation through glass, and heat conduction through glass [7]. Cooling Load calculation method is calculated by the method CLTD (Cooling Load Temperature Difference) [9]. The following of parameter data for calculating cooling load are used:

- Location in Surabaya, Indonesia

- Outside air conditions in Surabaya, Dry Bulb Temperature (DBT) : $34^{\circ} \mathrm{C}$

- Relative Humidity (RH) : $76 \%$

- Interior air condition is taken (design) DBT : $25^{\circ} \mathrm{C}, \mathrm{RH}$ : $60 \%$

- Occupant : $10 \mathrm{~m}^{2} /$ pers

- Working/hours : 8 AM - 6 PM : 10 hours/day

- Working/week : Monday - Friday : 5 days/week

- Sensible heat gain : $73 \mathrm{~W} /$ pers

- Latent heat gain : $59 \mathrm{~W} /$ pers

- Electrical power installed in lighting : $12 \mathrm{~W} / \mathrm{m} 2$

- Electrical power installed in electrical equipment : 10 $\mathrm{W} / \mathrm{m} 2$

\section{RESUlt AND DisCUSSION}

The results of the analysis in this article are simulations of square shapes of office buildings in Surabaya with the two simulation. After conducted OTTV analysis using formula (1). So, the results of the two simulations are as follows.

The first simulation of the orientation office building west, east, north, south. In the Figure 6. is the result of OTTV analysis that meets the requirements below $35 \mathrm{~W} /$ $\mathrm{m} 2$ in the first simulation, the results of the analysis obtained were 11 values under the OTTV requirements and there were 20 types of Asahimas glass. All of these results are obtained using a double glass. Some types of glass get the same value of OTTV, there are 5 types of glass that are the same, namely; VG (vision glass) $1, \mathrm{VG} 2, \mathrm{VG} 3, \mathrm{VG} 5$ and VG 10. The lowest Value of OTTV is $25.60 \mathrm{~W} / \mathrm{m} 2$ obtained on the glass type VG 1 .

The Second simulation of the orientation office building southwest, northwest, southeast, northeast. In Fig. 7. is the result of OTTV analysis on the 2 nd simulation. The results obtained value of OTTV that known the requirements, there are 11 values that meet the requirements of 20 types of glass. In the 2nd OTTV simulation the lowest was 25.93 $\mathrm{W} / \mathrm{m} 2$. Therefore the results of $2^{\text {nd }}$ simulation are the similiar as the $1^{\text {st }}$ simulation results. However in the $2^{\text {nd }}$ simulation the OTTV difference was higher by around $1.36 \%$ with the $1^{\text {st }}$ simulation.

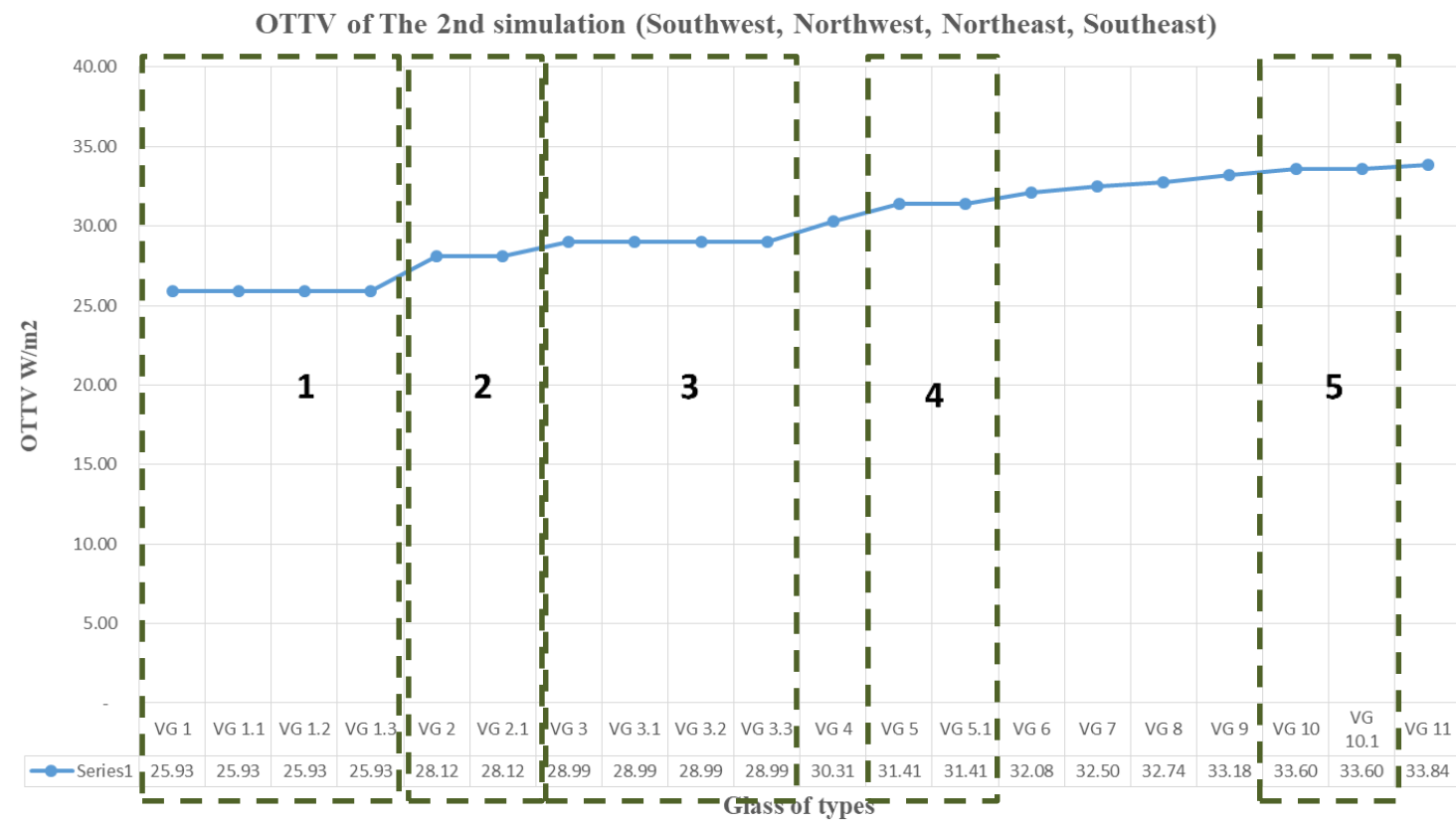

Figure 7. The Result OTTV with Glass types of the $2^{\text {nd }}$ simulation 
The $1^{\text {st }}$ International Conference on Business and Management of Technology (IConBMT)

August 3rd 2019, Institut Teknologi Sepuluh Nopember, Surabaya, Indonesia

TABLE 1.

TYPe OF DOUBLE GLAZING FAÇADE BY AGC

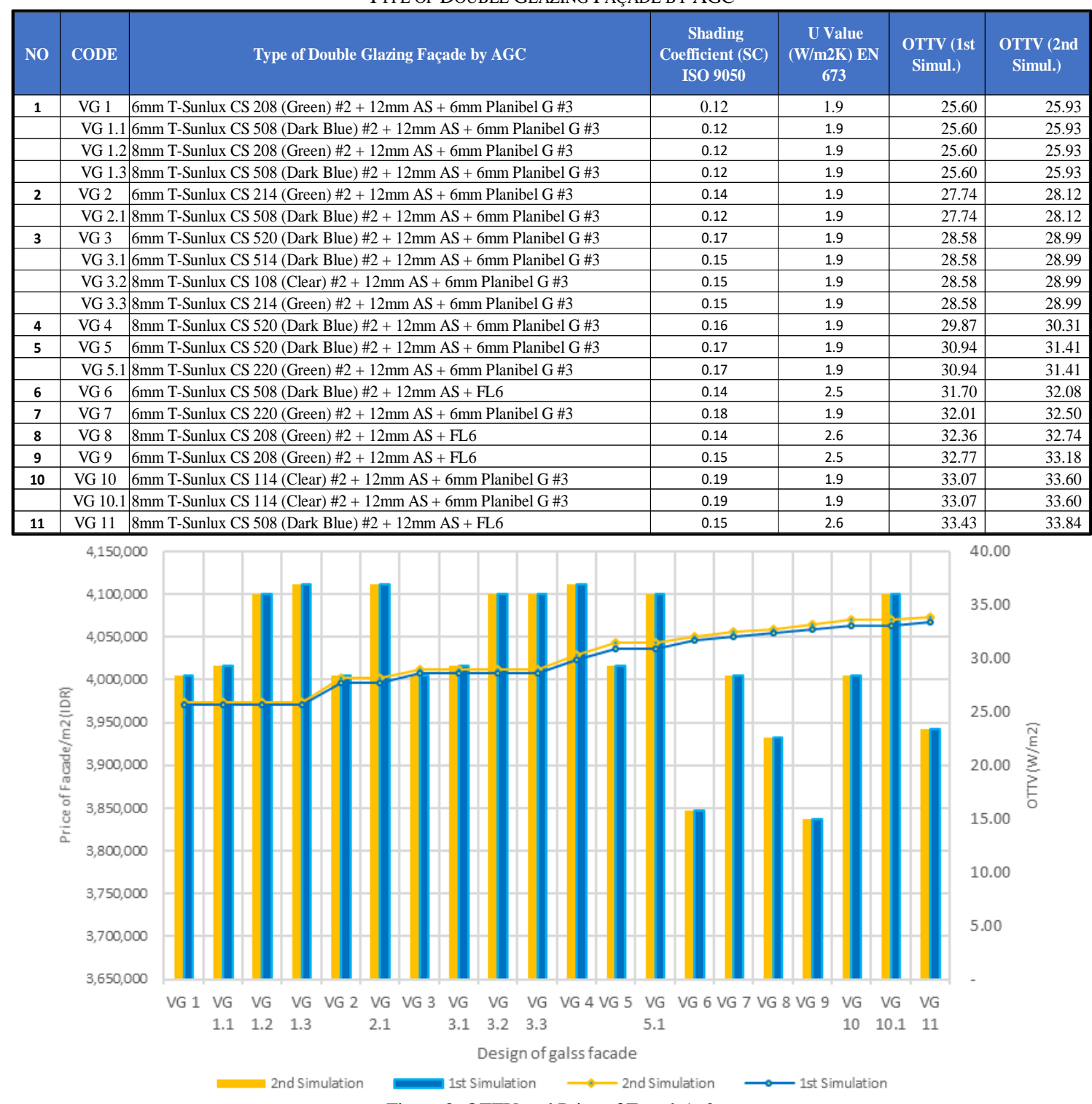

Figure 8. OTTV and Price of Façade/m2

In both simulations above, the majority of the types of glass obtained were using the T-Sunlux glass type with a double glass system. So that it can reduce solar heat gain. The different types of glass and OTTV are affected by different thicknesses of glass and glass combinations ( $\mathrm{T}$ sunlux). So that the shading coefficient (SC) and U value of the double glass are different.

The result of analysis glass of types can be seen in Table 1. The difference of simulation $1^{\text {st }}$ and simulation $2^{\text {nd }}$ influenced by $\mathrm{SC}$ dan $\mathrm{U}$ value. So, obtained $\mathrm{U}$ value glass $\leq 2.6 \mathrm{~W} / \mathrm{m}^{2} \mathrm{~K}$ and shading coefficient $(\mathrm{SC}) \leq 1.9$ which qualifies under $35 \mathrm{~W} / \mathrm{m} 2$. The type of glass that is known is double glass with code VG 1 until VG 1.3 obtains the lowest value of OTTV which is $25.60 \mathrm{~W} / \mathrm{m} 2 \quad\left(1^{\text {st }}\right.$ simulation) and $26.93 \mathrm{~W} / \mathrm{m} 2$ ( $2^{\text {nd }}$ simulation $) \mathrm{W} / \mathrm{m} 2$, while the highest OTTV scores were $33.43\left(1^{\text {st }}\right.$ simulation $)$ and $33.84\left(2^{\text {nd }}\right.$ simulation $) \mathrm{W} / \mathrm{m} 2$ were glass types with code VG 11 .

This research also calculates the cost of facade glass of office buildings according to facade specifications in section 3.2. the price of glass facade is based on interviews with one of the distributors authorized of Asahimas glass in Indonesia and one of the facade contractors in Surabaya.

The result of cost of glass facades are obtained can be seen in fig.8. in both simulations it is known to have the similiar facade / $\mathrm{m} 2$ price, because the type of glass taken based on previous OTTV results.

The lowest cost of glass facade found in glass type VG 9 which is Rp. 3,836,667 / m2 with the Value of OTTV btained which is $33.18 \mathrm{~W} / \mathrm{m} 2$. The difference in Value of 
OTTV is only $5.2 \%$ from the baseline and the difference in the price of the glass facade is $6.7 \%$ of the highest glass facade price. While the lowest Value of OTTV was obtained on glass type VG1 of $25.60 \mathrm{~W} / \mathrm{m} 2$ with the cost of glass facade of Rp. 4,005,333 / $\mathrm{m} 2$. The difference in cost of glass facade is only $2.6 \%$ and the difference in Value of OTTV obtained is $26 \%$ from the baseline.

However, the results of lowest OTTV such as the glass type VG1 until VG1.3 do $\mathrm{n}$ ot necessarily require a low façade price. Therefore the type of double glass combination greatly determines the price of facade / $\mathrm{m} 2$ even though the value of $\mathrm{SC}$ and $\mathrm{U}$ value meets the requirements. So that these results can be choice a type of glass for building owners.

Before the calculation of the cooling load analysis is known the results of roof $h$ eat recovery analysis (RTTV) which is $1,082 \mathrm{~W} / \mathrm{m} 2$. Analysis of RTTV calculations using formula 2 . Then after the results analysis of OTTV and RTTV are known, the next is an analysis of cooling load requirements. The cooling load analysis in this article uses formulas 5 to 9 . As well as the parameters mentioned in the methodology.

The results of the analysis heat gain load can be seen in fig.9. The results of heat gain it was obtained lowest $1.67 \mathrm{kWh} / \mathrm{m}^{2}\left(1^{\text {st }}\right.$ simulation $)$ and $1.68 \mathrm{kWh} / \mathrm{m}^{2}\left(2^{\text {nd }}\right.$ simulation). The lowest yield of heat $(\mathrm{kWh})$ was obtained from low OTTV. The lowest of heat gain load $(\mathrm{kWh} / \mathrm{m} 2)$ was obtained from low OTTV. The difference in heat gain load in both simulations obtained an average of $0.3 \%$ between simulations.

Then the heat recovery load is converted to BTU to determine the total cooling load requirements in the building. $1 \mathrm{kWh}$ is 3,412 BTU.

The results of the analysis of cooling load can be seen in fig.10. The lowest value of cooling load on 1st simulation is $7,669,981$ BTU or 5,707 BTU m2 obtained on VG 1 with value of OTTV $25.60 \mathrm{~W} / \mathrm{m} 2$. Then the highest value of cooling load on $1^{\text {st }}$ simulation is 8.092.675 BTU or 6.021 BTU / m2 obtained on VG 11 with Value of OTTV $33.43 \mathrm{~W} / \mathrm{m} 2$.

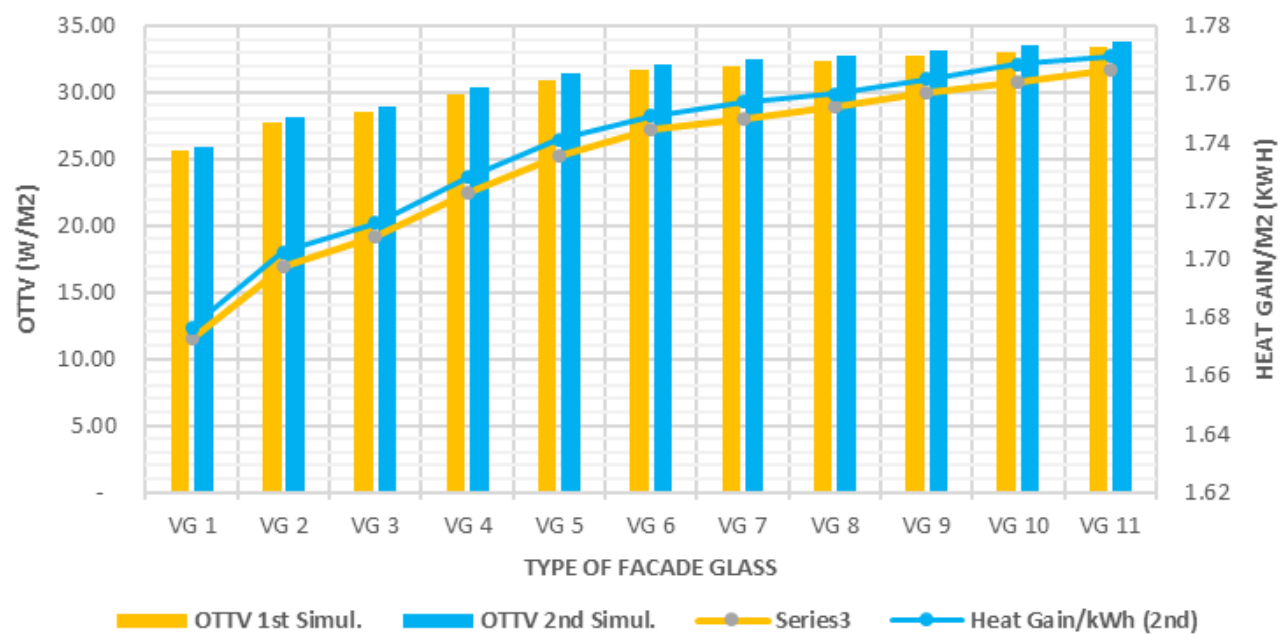

Figure .9. Effect OTTV to Heat gain/m2 $(\mathrm{kWh} / \mathrm{m} 2)$

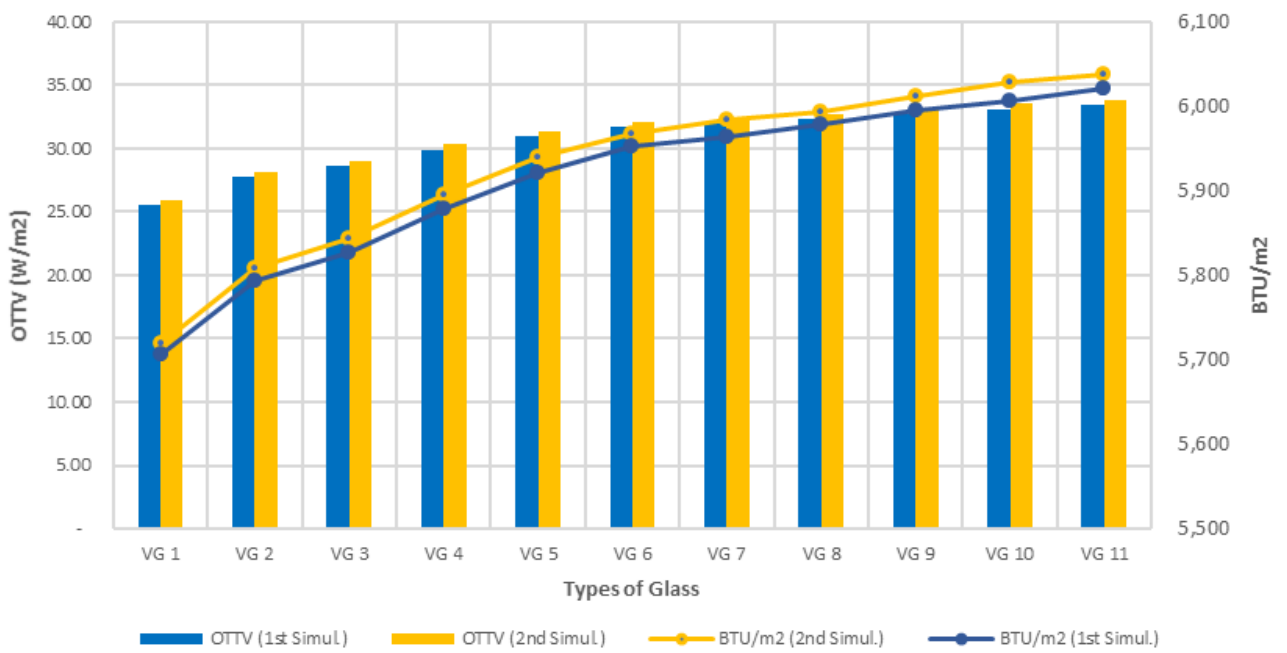

Figure 10. Effect OTTV to Cooling load /m2 (Btu/m2) 
The $1^{\text {st }}$ International Conference on Business and Management of Technology (IConBMT)

August 3rd 2019, Institut Teknologi Sepuluh Nopember, Surabaya, Indonesia

While the lowest cooling load in 2nd simulation is $7,687,816 \mathrm{BTU}$ or $5.720 \mathrm{BTU} / \mathrm{m} 2$ which is obtained at VG 1 with Value of OTTV $25.93 \mathrm{~W} / \mathrm{m} 2$. Then, the highest value of cooling load in $2^{\text {nd }}$ simulation is $8,114,969$ BTU or $6.038 \mathrm{BTU} / \mathrm{m} 2$ obtained on VG 11 with value of OTTV $33.84 \mathrm{~W} / \mathrm{m} 2$.

From these results it can be seen that the value of OTTV is very influential on the need for cooling loads. The lower of OTTV obtained, So the lower the cooling load requirement and also otherwise.

\section{CONCLUSION}

The results of the analysis obtained are there are differences in Value of OTTV between the $1^{\text {st }}$ simulation and $2^{\text {nd }}$ simulation the difference in average is $1.36 \%$ greater simulation in the SW, NW, NE, SE orientation using the same double glass type. The type of glass that is known is double glass with code VG 1 until VG 1.3 which can reduce up to $26 \%$ of the value of OTTV baseline. The orientation of the efficient simulation of this article is the orientation of West, East, North, South. The cost of glass facade in this study was taken based on the lowest Value of OTTV (VG1) of Rp. 4,005,333 / m2.

The most efficient type of glass facade of Asahimas products is T-sunlux of type glass with system doubleglass. In this research simulation the type of glass that gets the most efficient OTTV is the type of double glass $6 \mathrm{~mm}$ T-Sunlux CS 208-Green $+12 \mathrm{~mm}$ AS $+6 \mathrm{~mm}$ Planibel G (VG1).
The Value of OTTV of the building façade is very influential in obtaining heat and cooling loads. The simulation of this article it was found that the most efficient type of glass is double glass with SC (shading coeffient) $\leq 1.9$ and $U$ value glass $\leq 2.6 \mathrm{~W} / \mathrm{m}^{2} \mathrm{~K}$ which can reduce cooling load until $6.2 \%$.

\section{REFERENCES}

A. J. Santoso and I. G. N. Antaryama, "Konsekuensi energi akibat pemakaian bidang kaca pada bangunan tinggi di daerah tropis lembab," Dimens. (Journal Archit. Built Environ., vol. 33, no. 1, pp. 70-75, 2005.

[2] J. Priatman, “'FASADE KACA PINTAR' Teknologi inovatif bangunan tinggi hemat energi," Dimens. (Journal Archit. Built Environ., vol. 27, no. 7, pp. 76-84, 1999.

[3] Pemrov DKI Jakarta, Panduan Pengguna Bangunan Gedung Hijau, Vol. 1: Selubung Bangunan. Jakarta, Indonesia, 2012.

[4] E. Graiz and W. Al Azhari, "Energy efficient glass: A way to reduce energy consumption in office buildings in Amman (October 2018)," IEEE Access, vol. 7, pp. 61218-61225, 2019.

[5] S. Loekita and J. Priatman, "OTTV (SNI 03-6389-2011) and ETTV (BCA 2008) calculation for various building's shapes, orientations, envelope building materials: Comparison and analysis," Civ. Eng. Dimens., vol. 17, no. 2, pp. 108-115, 2015.

[6] BPSK Kota Surabaya, Statistik Daerah Kota Surabaya 2017. Surabaya, Indonesia: BPS Kota Surabaya, 2017.

[7] Badan Standar Nasional, SNI 6389:2011, tentang Konservasi energi selubung bangunan pada bangunan gedung. Jakarta, Indonesia: Badan Stadarisasi Nasional (BSN), 2011.

[8] S. Loekita, "Analisa konservasi energi melalui selubung bangunan,” Civ. Eng. Dimens., vol. 8, no. 2, pp. 93-98, 2006.

[9] Badan Standarisasi Nasional (BSN), SNI 6572:2001, tentang Tata cara perancangan sistem ventilasi dan pengkondisian udara pada bangunan gedung. Jakarta, Indonesia: Badan Stadarisasi Nasional (BSN), 2001. 